\title{
Perlakuan Termomekanik Paduan Mg-Gd Sebagai Material Implan Mampu Luruh
}

\author{
Oknovia Susanti $^{1{ }^{1) \star}}$, Sri Harjanto ${ }^{2)}$, Myrna A Mochtar $^{3)}$, Gunawarman $^{4)}$ \\ ${ }^{1,4)}$ Labor Metalurgi, Jurusan Teknik Mesin Universitas Andalas \\ kampus Limau Manis Padang \\ Email : oknovia.s@eng.unand.ac.id, gunawarman@eng.unand.ac.id \\ ${ }^{2,3)}$ Department Teknik Metalurgi dan Material, Fakultas Teknik Universitas Indonesia \\ Kampus UI Depok16424, Indonesia \\ Email : Harjanto@metal.ui.ac.id, $\underline{\text { myrna@metal.ui.ac.id }}$
}

doi: https://doi.org/10.24843/METTEK.2020.v06.i01.p01

\begin{abstract}
Abstrak
Paduan Mg-1,6Gd (wt\%) mempunyai potensial sebagai material implan yang mudah larut dalam tubuh. Penambahan Gd kedalam magnesium dan selanjut di proses melalui termomekanik bertujuan untuk memperbaiki sifat-sifat mekanik yaitu kekerasan, kekuatan, ketangguhan dan keuletan dan juga dapat mengontrol laju korosi dalam lingkungan biologis. Perubahan mekanik yang terbentuk akibat penambahan sedikit $\mathrm{Gd}$ $(1,6 \mathrm{wt} \%)$ kedalam Mg kemudian diproses termomekanik melalui ekstrusi dan rolling yang dikaitkan dengan hasil strukturmikro melalui ukuran butir dan phasa. Proses termomekanik dilakukan pada temperatur rekristalisasi $\left(400-550{ }^{\circ} \mathrm{C}\right)$ paduan $\mathrm{Mg}-1,6 \mathrm{Gd}$ dengan reduksi $95 \%$. Pemeriksaan dilakukan di skala labor dengan menggunakan tahaptahap metalografi dan pengujian tarik dengan ukuran sample yang standar ASTM E8. Uji kekerasan dengan menggunakan alat uji Hardness Vicker dengan berat 300 gram dan ditahan selama 15 detik. Pemerikasaan ini dilanjutkan dengan pengujian laju korosi dengan menggunakan cairan infus. Hasil menunjukan bahwa terjadi perubahan ukuran butir yang siknifikan pada paduan Mg-1,6Gd setelah proses termomekanik terutama pada proses ekstrusi panas yaitu mencapai $14 \mu \mathrm{m}$, namun kekerasan tertinggi terdapat pada proses pengerolan yaitu mencapai $50 \mathrm{HVN}$. Adanya sejumlah presipitat ditemui pada strukturmikro yang dapat mempengaruhi kekerasan akibat pengerolan. Sifat-sifat mekanik paduan Mg-1,6Gd juga dipengaruhi oleh presipitat, dimana kekuatan tertinggi adalah 197 MPa pada pengerolan dibanding ekstrusi hanya mencapai $187 \mathrm{MPa}$. Meskipun demikian keuletan terbesar dimiliki oleh pengerolan yaitu $26 \%$, sementara ekstrusi hanya mencapai $24 \%$. Pada pengujian korosi, pengerolan memiliki laju korosi yang lebih tinggi dibanding laju korosi ekstrusi yaitu 5,7 mmpy dalam larutan Ringer. Kedua proses termodinamik ini mempunyai peluang sebagai material implan yang mudah larut dalam tubuh, namun pengerolan lebih di rekomendasi baik dari sifat mekanik maupun laju korosi yang lebih terkontrol.
\end{abstract}

Kata kunci: Mg-1,6Gd, termomekanik, rekristalisasi, ekstrusi, pengerolan

\begin{abstract}
Mg-1,6Gd (wt\%) alloys has potential as a degradable materials implant. The addition of $G d$ in magnesium and then subsequently processed through thermo-mechanics aims to improve mechanical properties such as hardness, strength, toughness, ductility and can also control the rate of corrosion in the biological environment.Mechanical can be changed by the small addition of $\mathrm{Gd}(1.6 \mathrm{wt} \%)$ into $\mathrm{Mg}$ are then is processed through extrusion and rolling which are associated with grain size and phase. The
\end{abstract}

Penulis korespondensi,

Email: oknovia.s@eng.unand.ac.id 
thermomechanical process was carried out at a recrystallization temperature (400-550 $\left.{ }^{\circ} \mathrm{C}\right) . \mathrm{Mg}-1,6 \mathrm{Gd}$ alloys was hot rolled with a reduction of 95\%. The examination is carried out at a labor scale using metallographic steps and tensile testing with a standard of ASTM E8. Hardness test use the Hardness Vicker with 300 grams and held for 15 seconds. This examination is followed by testing the rate of corrosion using intravenous fluids. The results showed that there was a significant change in grain size in the Mg$1,6 G d$ alloys after the thermomechanical process, especially in the hot extrusion which reached $14 \mu \mathrm{m}$, but the highest hardness was found in the rolling process which reached $50 \mathrm{HVN}$. A number of precipitates are found in micro structures that can affect violence due to rolling. The mechanical properties of the $\mathrm{Mg}-1,6 \mathrm{Gd}$ alloys are also affected by the precipitate, where the highest strength is $197 \mathrm{MPa}$ on rolling compared to extrusion reaching only $187 \mathrm{MPa}$. However, the greatest tenacity is owned by rolling, which is $26 \%$, while extrusion only reaches $24 \%$. In corrosion testing, rolling has a higher corrosion rate than the extrusion corrosion rate of 5.7 mmpy in Ringer's solution. Both of these thermodynamic processes have opportunities as a degradable materials implant, but rolling is more recommended both in terms of mechanical properties and corrosion rates.

Keyword : Mg-1,6Gd alloys, Thermomechanics processsing, Recrystallization, Extrusion, rolling,

\section{PENDAHULUAN}

Tulang manusia adalah sebagai penopang hidup manusia, karena itu harus memiliki kekuatan, kekerasan, ketahanan aus, dan ketahanan fatik yang tinggi. Material logam mempunyai syarat yang tersebut di atas, jika dibandingkan dengan polimer atau keramik. Selama ini paduan logam yang digunakan sebagai implan antara lain baja tahan karat atau 316L yang dikenal sebagai ASTM F138, paduan kobalt-kromium (Co-Cr-Mo) yang dikenal sebagai ASTM F75 atau F799 dan Titanium (Ti-6Al-4V yang dikenal sebagai ASTM F136)[1-5]. Namun, paduan tersebut, mempunyai beberapa masalah selama penggunaan jangka panjang dalam tubuh. Pertama, ketidakcocokan antara sifat mekanik material dengan tulang, seperti modulus elastis material lebih besar dari tulang [6,7]. Perbedaan modulus ini bisa mencapai lebih dari $100 \%$, seperti modulus elastis untuk baja tahan karat adalah 200 $\mathrm{GPa}$, untuk kobal-kromium adalah 195-230 GPa, Titanium adalah $114 \mathrm{GPa}$, sementara tulang hanya memiliki sekitar 15-25 GPa[8]. Ketidakcocokan mekanis ini menghasilkan gejala klinis, dimana material implan memiliki tegangan yang besar, sementara jaringan tulang disekitarnya mengalami penurunan beban tegangan. Untuk mengatasi modulus elastis yang besar ini, sejumlah teknik sudah dilakukan, seperti menghasilkan logam berpori melalui serbuk logam disinter, injeksi gas ke logam dan lainnya. Namun pembuatan logam berpori ini memiliki keterbatasan untuk penggunaan ortopedi seperti kerapuhan, kontrol terbatas terhadap ukuran, bentuk dan distribusi porositas [9]. Masalah kedua adalah pelepasan ion-ion atau partikel selama penanaman implan jangka panjang dalam tubuh seperti ion krom, nikel dan kobalt, sehingga dapat mengurangi biokompatibilitas material implan [10,11]. Sementara untuk paduan Titanium (Ti-6Al-4V) juga menghasilkan racun disebabkan unsur vanadium pada tubuh dalam pemakaian yang cukup lama [12], sehingga unsur tersebut digantikan oleh niobium dan besi seperti Ti-6Al-7Nb dan Ti-5Al-2.5Fe [13, 14]. Masalah ketiga adalah material implan tersebut harus dikeluarkan kembali, bila jaringan tulang sudah tumbuh. Hal ini dapat menyulitkan pasien, baik dari segi biaya dan kelemahan fisik dengan adanya operasi kedua [15].

Paduan magnesium telah menunjukkan spesifik sifat mekanik dan biokompabilitas baik pada tubuh manusia, sehingga sangat menarik untuk terus dikembangkan sebagai material degradable (mudah larut). Secara mekanik, magnesium mempunyai sifat mekanik yang hampir sama dengan tulang seperti modulus elastis sekitar 41-45 GPa yang mendekati dengan modulus elastis tulang manusia sekitar 15-25 GPa [8]. Beberapa paduan Mg telah 
dikembangkan sebagai material implan mudah larut seperti paduan $\mathrm{MgCa}$ yang diteliti oleh Hagihara dkk, 2014,[16], paduan MgZn dikembangkan oleh Zhang dkk, 2010 [17] dan paduan MgSr oleh Wang, 2017 [18]. Paduan Mg sebagai material implan mudah larut terus dikembangkan untuk memperbaiki perilaku korosi dan biokompatibilitas dengan cara mengoptimalkan komposisi unsur-unsur paduan dan proses mekanik.

Saat ini unsur-unsur tanah jarang (rare earth) juga menjadi perhatian untuk ditambahkan ke dalam magnesium sebagai material implan mudah larut. Secara umum, unsurunsur tanah jarang seperti unsur Y, Gd, Tb, Dy, Ho, Er, Tm, Yb dan Lu, Nd, La, Ce, Pr, Sm dan $\mathrm{Eu}$ dapat memperbaiki sifat-sifat mekanik (keuletan, kekuatan tarik, luluh) dan biokompatilitas [19]. Unsur-unsur ini di dalam magnesium harus memiliki batas kelayakan berkisar 1-4 wt \% sebagai material implan dengan menggunakan standar ISO 3116: 2007 dan EN 17531997 [20]. Unsur ini dapat mengubah sifat mekanik melalui penguatan persipitat dan penguatan larutan padat (precipitate strengthening dan solid solution strengthening) [21]. Disamping mempengaruhi sifat mekanik, unsur tanah jarang juga mempengaruhi perilaku korosi yang sangat penting dalam perancangan material implan.

Mekanisme unsur tanah jarang dalam menghambat laju korosi adalah :

1. Unsur tanah jarang menghasilkan fasa intermetalik yang dapat mengikat kotoran seperti Fe, $\mathrm{Ni}$ dan Co, dimana pengotor tersebut dapat mempercepat terjadinya korosi pada paduan $\mathrm{Mg}$ [22].

2. Atom-atom unsur tanah jarang berintereaksi dengan $\mathrm{Cl}^{-}$yang berfungsi meningkatkan stabilitas dan pelindung dari efek korosi[23].

Gadolinium adalah salah satu unsur tanah jarang dengan kelarutan padat tinggi, penambahan sedikit gadolinium kedalam magnesium dapat meningkatkan sifat-sifat mekanik melalui pembentukan endapan intermetalik $\mathrm{Mg}_{5} \mathrm{Gd}$ dan larutan padat (solid solution). Paduan biner Mg-Gd mengandung Gd kurang $10 \%$ menunjukan pengerasan yang baik karena adanya mekanisme persipitat lewat jenuh. Pada penelitian ini dilakukan penambahan sedikit gadolonium ke dalam magnesium dan selanjutnya di proses dengan proses termomekanik melalui ekstrusi dan pengerolan panas.

\section{METODE}

Ingot paduan $\mathrm{Mg}-1,6 \mathrm{Gd}$ di homogenisasi selama 5 jam pada temperatur $560{ }^{\circ} \mathrm{C}$ dan selanjutnya pendinginan normal (Normalizing). Sampel disiapkan dengan pengerolan panas dengan dua metode yaitu pengerolan searah (UR) dan pengerolan bolak balik dengan ukuran $50 \mathrm{~mm} \times 25 \mathrm{~mm} \times 10 \mathrm{~mm}$. Pengerolan panas ini dilakukan dengan kecepatan $10 \mathrm{~mm} / \mathrm{min}$ pada temperatur dari $400-550^{\circ} \mathrm{C}$ dengan reduksi $95 \%$ dan setiap tahap rolling di reduksi 23 , $75 \%$. Ketebalan akhir dari pengerolan panas ini adalah sekitar $3 \mathrm{~mm}$. Tahap-tahap metalografi dilakukan untuk mendapatkan hasil struktur mikro. Sampel diamplas sampai kekasaran $2000 \mu \mathrm{m}$ dan selanjutnya di poles dengan pasta alumina. Larutan etsa disiapkan berisi $20 \mathrm{ml}$ asam asetat $+1 \mathrm{ml}$ asam nitrat $+60 \mathrm{ml}$ etileglicol $+20 \mathrm{ml}$ aquades selama sekitar 15 detik. Kemudian spesimen diamati menggunakan mikroskop optik.

Uji kekerasan dilakukan dengan Hardness Vicker dengan beban 300g selama 15 detik waktu penekanan. Jumlah penekanan adalah 10 titik pada masing-masing sampel hasil pengerolan. Sampel uji tarik yang memiliki panjang pengukur $24 \mathrm{~mm}$ diambil sejajar dengan arah pengerolan dengan menggunakan standar ASTM E8-04. Tes uji tarik dilakukan dengan mesin uji tarik uniaksial (Gotech AI-7000 LA10) pada suhu kamar. Selanjutnya, morfologi permukaan patah diamati dengan menggunakan SEM. 


\section{HASIL DAN PEMBAHASAN \\ 3.1 Struktur Mikro}

Struktur mikro paduan Mg-1.6Gd menghasilkan ukuran butir yang kecil pada masing-masing temperatur pengerolan seperti yang ditunjukkan pada Gambar 1 dan 2 . Gambar 1 menunjukkan pengerolan panas searah (UR) pada setiap temperatur. Secara umum, ukuran butiran pengerolan searah (UR) lebih kecil dari pengerolan panas bolak balik (CR). Rata-rata ukuran butir pengerolan panas searah (UR) adalah sekitar $70 \mu \mathrm{m}$. Ukuran butir bertambah dengan bertambahnya temperatur pengerolan dimana ukuran butir meningkat dari $72 \mu \mathrm{m}\left(452^{\circ} \mathrm{C}\right)$ menjadi $89 \mu \mathrm{m}\left(560^{\circ} \mathrm{C}\right)$. Semua pengerolan panas menunjukkan struktur lamella dengan arah yang berbeda. Struktur tajam phasa $\mathrm{Mg}(\alpha-\mathrm{Mg})$ dihasilkan pada temperatur pengerolan $491^{\circ} \mathrm{C}$.
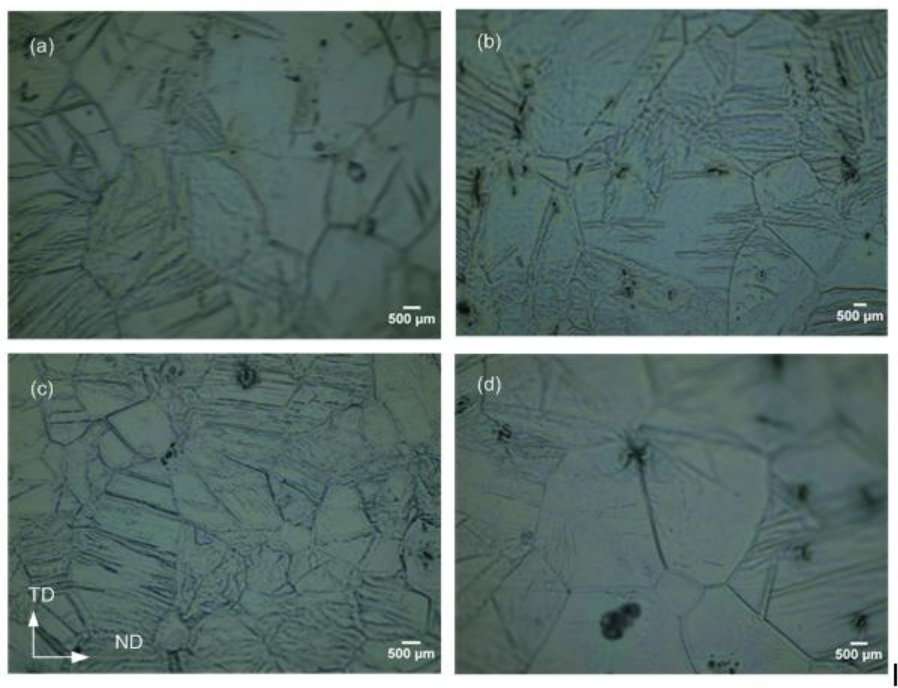

Gambar 1. Struktur mikro paduan $\mathrm{Mg}-1,6 \mathrm{Gd}$ setelah di rolling panas searah (UR) dengan reduksi $95 \%$ pada variasi temperatur : (a) $400^{\circ} \mathrm{C}$, (b) $452^{\circ} \mathrm{C}$, (c) $491^{\circ} \mathrm{C}$ and (d) $560^{\circ} \mathrm{C}$

Gambar 2 menunjukkan struktur mikro dari pengerolan panas bolak balik (CR) yang memiliki ukuran butiran lebih besar dibandingkan dengan pengerolan searah dan lebih homogen (seragam). Pada temperatur $410^{\circ} \mathrm{C}$ dipengerolan bolak balik, memiliki ukuran butir $127 \mu \mathrm{m}$ dan ukuran butir turun menjadi $64 \mu \mathrm{m}$ pada temperatur tertinggi $561{ }^{\circ} \mathrm{C}$. Ukuran butir yang paling kecil ditemukan pada temperatur $521^{\circ} \mathrm{C}$ dengan ukuran butir $56 \mu \mathrm{m}$. Proses ini menghasilkan sejumlah lamella, yang mana ditemukan paling banyak pada temperatur $410{ }^{\circ} \mathrm{C}$. Endapan terbentuk di temperatur yang paling tinggi. Partikel-partikel endapan itu membentuk phasa $\mathrm{Mg}_{5} \mathrm{Gd}$, seperti yang di jelaskan oleh Hort et al in phase diagram [24]. Paduan $\mathrm{Mg}$ 1,6Gd dalam kondisi yang berbeda pada suhu di bawah $500{ }^{\circ} \mathrm{C}$ membentuk larutan padat melalui $\alpha-\mathrm{Mg}$ dan phasa kedua atau pengendapan $\mathrm{Mg}_{5} \mathrm{Gd}$. Oleh sebab itu, pengendapan partikel pada pengerolan bola balik ini, sangat jelas di temukan di temperatur $400-550^{\circ} \mathrm{C}$. Terbentuknya endapan ini bertambah dengan bertambahnya temperatur pengerolan. 

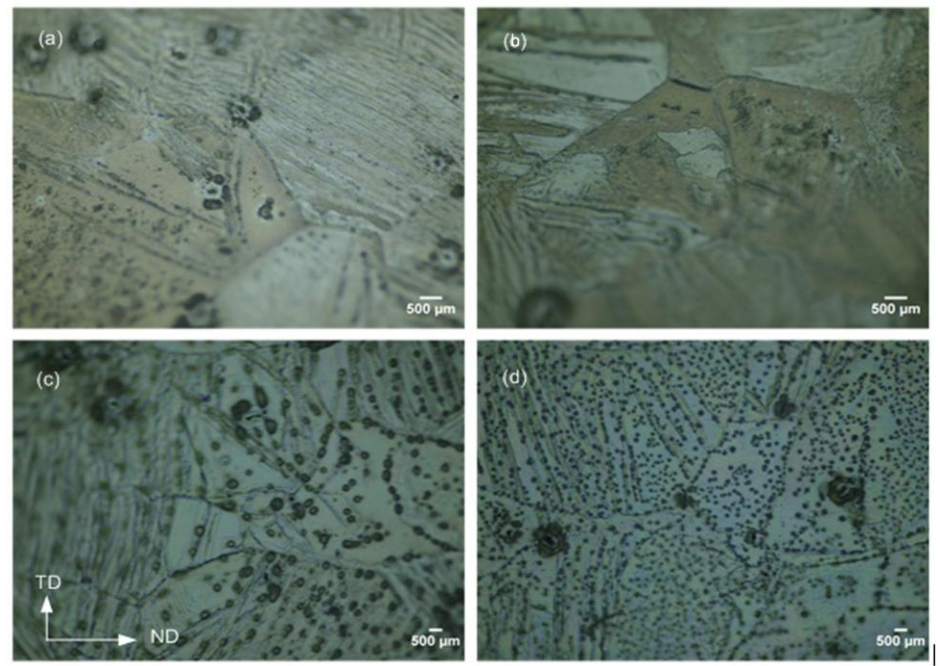

Gambar 2.: Struktur mikro paduan $\mathrm{Mg}-1,6 \mathrm{Gd}$ setelah di rolling panas bolak balik (CR) dengan reduksi $95 \%$ pada variasi temperatur (a) $410^{\circ} \mathrm{C}$, (b) $455^{\circ} \mathrm{C}$, (c) $521^{\circ} \mathrm{C}$ and (d) $561^{\circ} \mathrm{C}$

Pengaruh temperatur pada ukuran butir dari kedua metode pengerolan yaitu UR dan CR ditunjukkan pada Gambar 3. Ukuran butiran sampel UR relatif sama pada setiap temperatur pengerolan. Namun, untuk sampel CR, pada temperatur di bawah $500{ }^{\circ} \mathrm{C}$ memberikan ukuran butir lebih besar daripada sampel UR pada saat yang sama.

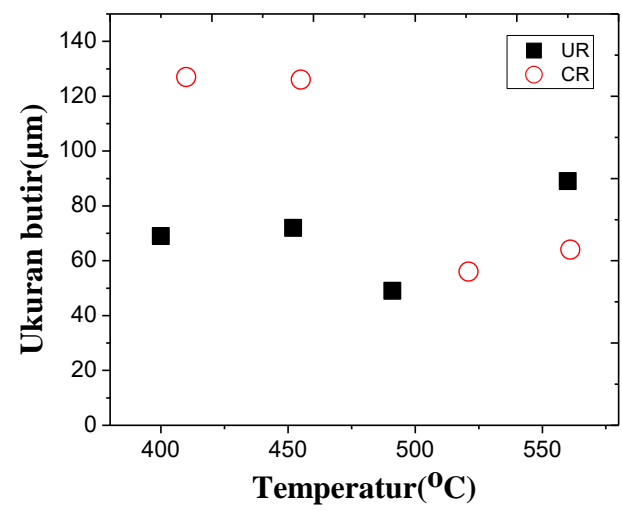

Gambar 3. Ukuran butir paduan Mg-1,6Gd setelah pengerolan searah dan pengerolan bola balik di variasi temperatur.

\subsection{Sifat-sifat Mekanik}

Sifat-sifat kekerasan yang diamati pada kedua proses pengerolan panas searah (UR) dan pengerolan bolak balik (CR) dengan reduksi $95 \%$ ditunjukkan pada gambar 4 . Nilai kekerasan paduan Mg-1,6Gd berada dalam kisaran 40 sampai $51 \mathrm{HVN}$. Secara umum, nilai kekerasan yang diamati untuk sampel CR lebih tinggi dari pada untuk sampel UR. Kekerasan paling tinggi paduan $\mathrm{Mg}-1.6 \mathrm{Gd}$ adalah $50,8 \mathrm{HVN}$, pada pengerolan bolak balik (CR) di temperatur $561{ }^{\circ} \mathrm{C}$. Pada temperatur $400^{\circ} \mathrm{C}$ dan $450^{\circ} \mathrm{C}$, kekerasan sampel UR dan CR adalah 40,3 HVN dan 40,9 HVN. Pada suhu CR $410^{\circ} \mathrm{C}$, nilai kekerasan adalah $42 \mathrm{HVN}$. Untuk sampel $\mathrm{CR}$, nilai kekerasan pada $455^{\circ} \mathrm{C}$ dan $521^{\circ} \mathrm{C}$ hampir sama, sekitar $44 \mathrm{HVN}$. Namun, nilai kekerasan meningkat secara dramatis pada $561^{\circ} \mathrm{C}$ menjadi sekitar $51 \mathrm{HVN}$. 


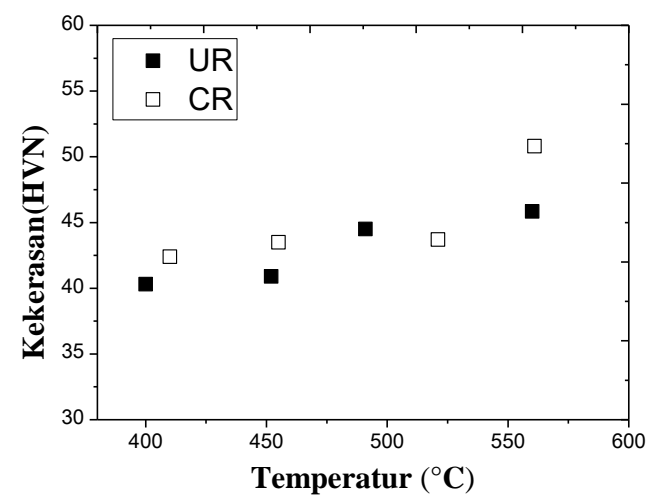

Gambar 4. Kekerasan paduan $\mathrm{Mg}-1,6 \mathrm{Gd}$ setelah pengerolan panas searah dan bolak balik dengan reduksi $95 \%$.

Sifat-sifat mekanik dari paduan yang dihasilkan dari dua metode pengerolan panas yang berbeda ditampilkan pada Gambar 5. Dapat dilihat bahwa kekuatan dan perpanjangan paduan setelah pengerolan panas meningkat secara siknifikan. Gambar. 5a menunjukkan sifat tarik paduan $\mathrm{Mg}-1.6 \mathrm{Gd}$ pengerolan panas pada temperatur yang berbeda untuk pengerolan UR dan CR. Pada semua temperatur, kekuatan tarik utama sampel UR lebih tinggi dari sampel CR. Kondisi ini mungkin disebabkan oleh banyak lamella dalam partikel-partikel. Nilai kekuatan meningkat dengan meningkatnya temperatur rolling. Pada temperatur $400{ }^{\circ} \mathrm{C}$, nilai kekuatan adalah $181 \mathrm{MPa}$ dan, selanjutnya, nilai kekuatan naik menjadi $188 \mathrm{MPa}$ dan 197 MPa pada masing-masing temperatur $452^{\circ} \mathrm{C}$ dan $491^{\circ} \mathrm{C}$, masing-masing. Kekuatan turun secara berlahan ke $195 \mathrm{MPa}$ pada temperatur tertinggi $\left(560{ }^{\circ} \mathrm{C}\right)$. Kekuatan tarik tertinggi untuk sampel CR adalah $164 \mathrm{MPa}$ pada temperatur $521^{\circ} \mathrm{C}$. Pada temperatur yang lebih rendah $410{ }^{\circ} \mathrm{C}$, nilai kekuatan tarik adalah $157 \mathrm{MPa}$ yang kemudian turun menjadi $103 \mathrm{MPa}$ pada temperatur $455^{\circ} \mathrm{C}$. Kekuatan tarik turun secara signifikan ke $93 \mathrm{MPa}$ pada temperatur $561^{\circ} \mathrm{C}$.

Gambar 5b menampilkan nilai kekuatan luluh pada temperatur yang berbeda. Secara umum, kekuatan luluh sampel UR lebih tinggi dari sampel CR. Sampel UR menunjukkan kekuatan tarik tertinggi $157 \mathrm{MPa}$ pada suhu $560^{\circ} \mathrm{C}$, sedangkan kekuatan luluh terendah sampel CR sekitar $93 \mathrm{MPa}$ diamati pada temperatur rolling panas tertinggi $561^{\circ} \mathrm{C}$. Rata-rata, perpanjangan sampel UR lebih besar dari sampel CR. Keuletan Mg-1,6Gd setelah pengerolan panas dengan UR atau CR pada berbagai temperatur, seperti yang ditunjukkan pada gambar 5 c, berada dalam kisaran 5-26\%. Keuletan tertinggi sampel UR adalah $26 \%$ pada temperatur $491{ }^{\circ} \mathrm{C}$. Sampel CR menunjukkan perpanjangan tertinggi $17 \%$ pada temperatur yang sedikit lebih tinggi seperti yang ditunjukkan pada Gambar 5c. Kedua, kekuatan tarik pamungkas dan kekuatan luluh paduan Mg-1.6 meningkat setelah rolling panas dan keuletan juga meningkat, terutama dalam sampel UR. 


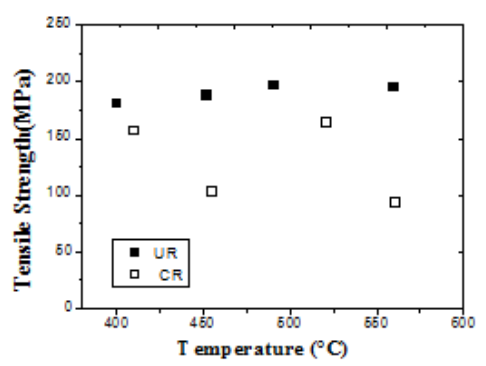

(a)

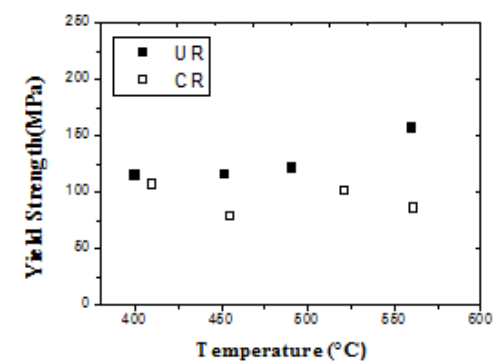

(b)

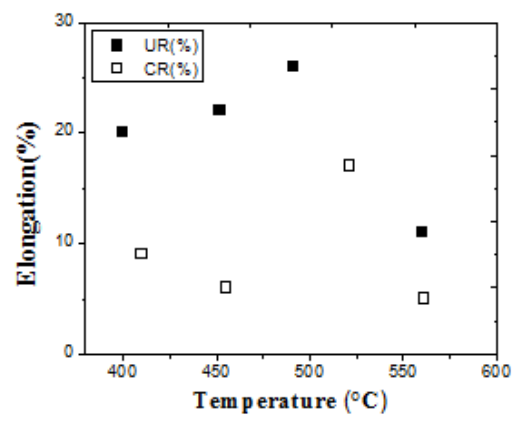

(c)

Gambar 5. (a). Kekuatan tarik (UTS), (b). Kekuatan luluh (YS) and (c).Keuletan paduang $\mathrm{Mg}-1,6 \mathrm{Gd}$ setelah di rolling panas searah (UR) dan rolling panas bolak balik di variasi temperatur

Rekristalisasi terjadi selama pengerolan panas, yang ditampilkan pada Gambar 6 dan 7. Gambar-gambar fraktografi ini menunjukkan sejumlah dimple (lubang kecil) dan patah tajam. Fraktografi paduan UR dan CR Mg-1,6Gd ditunjukkan pada Gambar 6 dan 7. Untuk sampel UR, ditemukan bahwa gambar 6(a),(b)dan,(c) menunjukkan patah ulet dominan karena ditemukan dimple kasar. Namun, pada Gambar 6(d), permukaan patah menghasilkan patah brittle seperti yang ditunjukkan dalam tanda persegi.
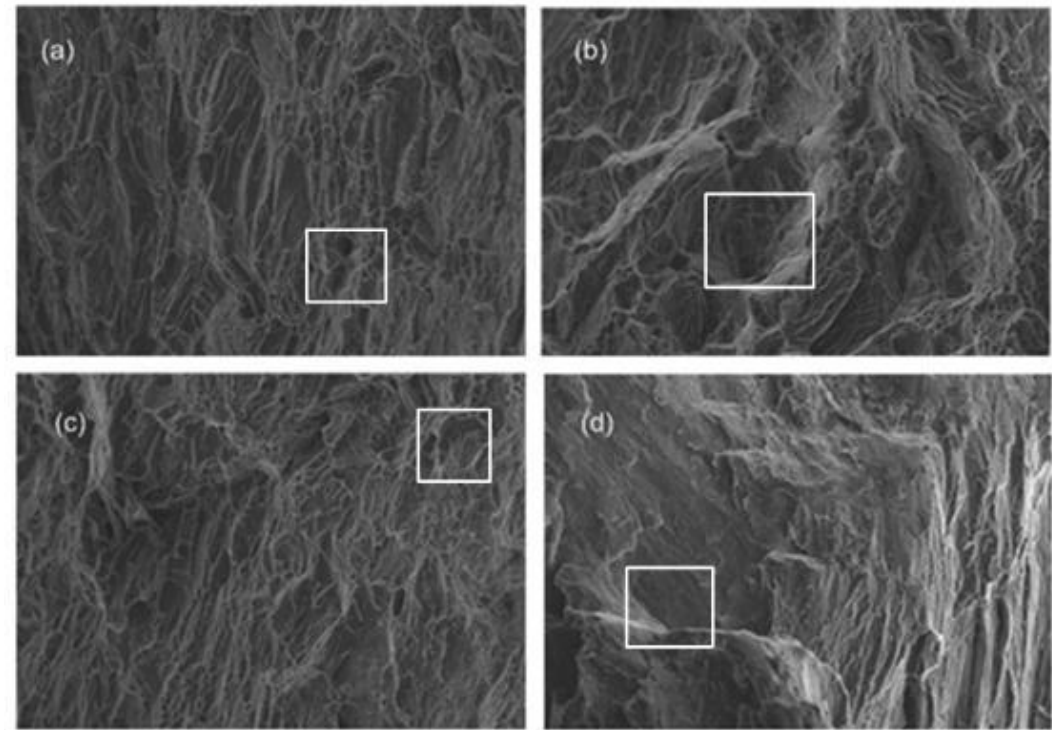

Gambar 6. Permukaan patah pada paduan Mg-1,6Gd yang di rolling searah di temperatur. (a) $400{ }^{\circ} \mathrm{C}$, (b) $452{ }^{\circ} \mathrm{C}$, (c) $491{ }^{\circ} \mathrm{C}$, (d) $560{ }^{\circ} \mathrm{C}$. Dimples di tunjukkan dalam tanda persegi. 
Fraktografi SEM dari sampel uji tarik pada CR ditunjukkan pada Gambar 7. Permukaan patah dari paduan di rolling panas menghasilkan sejumlah dimple dan patahan. Pada gambar 7 (a), (b) dan, (c) dimple sangat sedikit. Hal ini sangat relevan yang menunjukkan bahwa pengerolan bolak balik lebih cenderung patah getas. Namun, permukaan patah sampel $\mathrm{CR}$ pada suhu $521^{\circ} \mathrm{C}$ mempunyai sejumlah dimple memiliki keuletan yang tinggi $17 \%$ dibandingkan sampel lainnya.
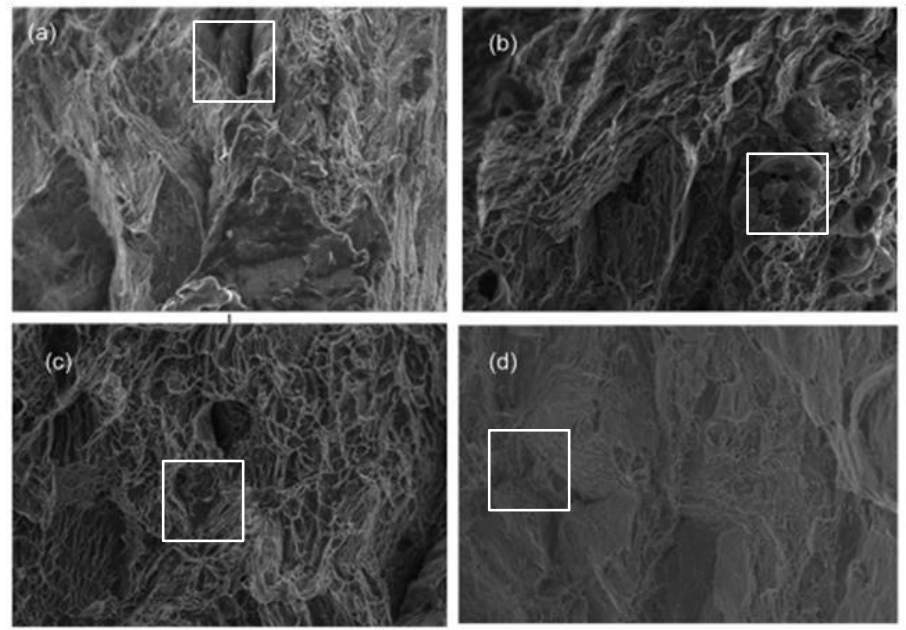

Gambar 7. Permukaan patah paduan Mg-1,6Gd di rolling bolak balik (CR) pada temperatur :(a) $410{ }^{\circ} \mathrm{C}$, (b) $455^{\circ} \mathrm{C}$, (c) $521{ }^{\circ} \mathrm{C}$, (d) $561^{\circ} \mathrm{C}$. Dimples ditunjukkan dengan kotak persegi.

\section{SIMPULAN}

Pengamatan struktur mikro dari paduan $\mathrm{Mg}-1,6 \mathrm{Gd}$ dirolling dengan dua metode (UR dan CR) pada di temperatur $400-550{ }^{\circ} \mathrm{C}$ menghasilkan :

1. Fasa lamella yang merupakan phasa kaya $\mathrm{Mg}(\alpha-\mathrm{Mg})$, ditemukan dalam sampel UR dan CR di semua temperatur dan sejumlah presipitasi $\left(\mathrm{Mg}_{5} \mathrm{Gd}\right)$ terbentuk dan menyebar.

2. Struktur mikro sampel UR memiliki ukuran butiran yang lebih kecil dibandingkan dengan sampel CR terutama yang di bawah $500^{\circ} \mathrm{C}$

3. Paduan Mg-1.6Gd dengan kekuatan tinggi dan keuletan tinggi dapat ditingkatkan dengan pengerolan panas pada daerah temperatur kristalisasi. Uji tarik menunjukkan bahwa sampel UR menunjukkan sifat mekanik yang sedikit lebih baik daripada sampel CR. Kedua, sampel UR dan CR menunjukkan kekuatan tinggi dan keuletan masing-masing sekitar 121 MPa (26\%) untuk UR dan $101 \mathrm{MPa}(17 \%)$ untuk CR. Hal ini sangat berkaitan dengan pengamatan permukaan patah yang menampilkan banyak dimple pada kedua pengerolan. Nilai kekerasan sampel CR umumnya lebih tinggi dari sampel UR. Kekerasan puncak paduan $\mathrm{Mg}-1.6 \mathrm{Gd}$ adalah 50,8 $\mathrm{HVN}$.

\section{DAFTAR PUSTAKA}

[1] R. Singh and N. B. Dahotre, "Corrosion degradation and prevention by surface modification of biometallic materials," Journal of Materials Science: Materials in Medicine, vol. 18, pp. 725-751, 2007.

[2] M. Moravej and D. Mantovani, "Biodegradable metals for cardiovascular stent application: interests and new opportunities," International journal of molecular sciences, vol. 12, pp. 4250-4270, 2011.

[3] I. A. L. Lim, "Biocompatibility of stent materials," Murj, vol. 11, p. 34, 2004. 
[4] R. L.L, Magnesium Alloys Containing Rare Earth Metals: Taylor and Francis London, 2003.

[5] M. Niinomi, "Recent metallic materials for biomedical applications," Metallurgical and materials transactions A, vol. 33, pp. 477-486, 2002.

[6] Y. F. Zheng, X. N. Gu, and F. Witte, "Biodegradable metals," Materials Science and Engineering: R: Reports, vol. 77, pp. 1-34, 2014/03/01/ 2014.

[7] X. Ye, L. Wang, Z. T. H. Tse, G. Tang, and G. Song, "Effects of high-energy electropulsing treatment on microstructure, mechanical properties and corrosion behavior of Ti-6Al-4V alloy," Materials Science and Engineering: $C$, vol. 49, pp. 851-860, 2015/04/01/ 2015.

[8] S. Agarwal, J. Curtin, B. Duffy, and S. Jaiswal, "Biodegradable magnesium alloys for orthopaedic applications: A review on corrosion, biocompatibility and surface modifications," Materials Science and Engineering: C, vol. 68, pp. 948-963, 11/1/ 2016.

[9] B. Vamsi Krishna, W. Xue, S. Bose, and A. Bandyopadhyay, "Engineered porous metals for implants," JOM, vol. 60, pp. 45-48, May 012008.

[10] C. Lhotka, T. Szekeres, I. Steffan, K. Zhuber, and K. Zweymüller, "Four-year study of cobalt and chromium blood levels in patients managed with two different metal-onmetal total hip replacements," Journal of Orthopaedic Research, vol. 21, pp. 189-195, 2003.

[11] M. P. Staiger, A. M. Pietak, J. Huadmai, and G. Dias, "Magnesium and its alloys as orthopedic biomaterials: a review," Biomaterials, vol. 27, pp. 1728-1734, 2006.

[12] S. Steinemann, "Corrosion of titanium and titanium alloys for surgical implants," Titanium--Science and Technology., vol. 2, pp. 1373-1379, 1984.

[13] M. F. Semlitsch, H. Weber, R. M. Streicher, and R. Schön, "Joint replacement components made of hot-forged and surface-treated Ti-6Al-7Nb alloy," Biomaterials, vol. 13, pp. 781-788, 1992.

[14] K.-H. Borowy and K.-H. Kramer, "On the Properties of a New Titanium Alloy(TiAl 5 Fe 2. 5) as Implant Material," Titanium--Science and Technology., vol. 2, pp. 13811386, 1984.

[15] J. B. Park and J. D. Bronzino, Biomaterials: principles and applications: crc press, 2002.

[16] P.-C. Wong, P.-H. Tsai, T.-H. Li, C.-K. Cheng, J. S. C. Jang, and J. C. Huang, "Degradation behavior and mechanical strength of $\mathrm{Mg}-\mathrm{Zn}-\mathrm{Ca}$ bulk metallic glass composites with $\mathrm{Ti}$ particles as biodegradable materials," Journal of Alloys and Compounds, vol. 699, pp. 914-920, 2017/03/30/ 2017.

[17] S. Zhang, X. Zhang, C. Zhao, J. Li, Y. Song, C. Xie, et al., "Research on an Mg-Zn alloy as a degradable biomaterial," Acta Biomaterialia, vol. 6, pp. 626-640, 2010/02/01/ 2010.

[18] Y. Wang, D. Tie, R. Guan, N. Wang, Y. Shang, T. Cui, et al., "Microstructures, mechanical properties, and degradation behaviors of heat-treated $\mathrm{Mg}-\mathrm{Sr}$ alloys as potential biodegradable implant materials," Journal of the Mechanical Behavior of Biomedical Materials, vol. 77, pp. 47-57, 2018/01/01/2018.

[19] N. Stanford, I. Sabirov, G. Sha, A. La Fontaine, S. Ringer, and M. Barnett, "Effect of $\mathrm{Al}$ and Gd solutes on the strain rate sensitivity of magnesium alloys," Metallurgical and Materials Transactions A, vol. 41, pp. 734-743, 2010.

[20] X. Gu, Y. Zheng, Y. Cheng, S. Zhong, and T. Xi, "In vitro corrosion and biocompatibility of binary magnesium alloys," Biomaterials, vol. 30, pp. 484-498, 2009. 
[21] M. Pekguleryuz, "5 - Alloying behavior of magnesium and alloy design," in Fundamentals of Magnesium Alloy Metallurgy, ed: Woodhead Publishing, 2013, pp. 152-196.

[22] T. Takenaka, T. Ono, Y. Narazaki, Y. Naka, and M. Kawakami, "Improvement of corrosion resistance of magnesium metal by rare earth elements," Electrochimica Acta, vol. 53, pp. 117-121, 2007.

[23] H. B. Yao, Y. Li, A. T. S. Wee, J. S. Pan, and J. W. Chai, "Correlation between the corrosion behavior and corrosion films formed on the surfaces of Mg82-xNi18Ndx $(\mathrm{x}=0,5,15)$ amorphous alloys," Applied Surface Science, vol. 173, pp. 54-61, 2001/03/22/ 2001.

[24] N. Hort, Y. Huang, D. Fechner, M. Störmer, C. Blawert, F. Witte, et al., "Magnesium alloys as implant materials-principles of property design for $\mathrm{Mg}-\mathrm{RE}$ alloys," Acta biomaterialia, vol. 6, pp. 1714-1725, 2010. 